\title{
Mendudukkan Posisi Ijtihad Nabi Muhammad dalam Teks Ajaran Islam
}

\author{
Muhib Rosyidi ${ }^{1}$
}

\begin{abstract}
This article discusses the ijtihad of Rasulullah Saw., in relation to the teachings of Islam. Using a descriptive-analytic method, this library research examines various situations of Muhammad as the Prophet and the Messenger in implementing his daily missions. It finds that real life with its complex situations including the situation which necessitates Muhammad to deploy his own judgment of ijtihad. His position as the Prophet, and Messenger makes his ijtihad treated naturally as higher ijtihad than other Muslim's ijtihad in general. It is therefore, his ijtihad places him at special place in the Islamic teachings.
\end{abstract}

\begin{abstract}
Abstrak
Tulisan ini membahas ijtihad Rasulullah Saw. dalam kaitannya dengan ajaran Islam. Dengan pendekatan deskriptif-analitik, studi kepustakaan ini mengkaji berbagai keadaan Muhammad sebagai manusia biasa dan sebagai Nabi dan Rasul dalam menjalankan misinya sehari-hari. Studi ini menemukan bahwa kehidupan nyata dengan segala kompleksitasnya termasuk situasi yang menuntut jawaban yang segera menempatkan Muhammad melakukan ijtihad. Posisinya sebagai Nabi dan Rasul membuat ijtihadnya secara alamiah dianggap lebih penting dari ijtihad Muslim pada umumnya. Oleh karenanya, ijtihadnya menempati posisi tersendiri dalam ajaran Islam.
\end{abstract}

Keywords: Muhammad Saw, Kenabian, Ijtihad, dan Wahyu.

\section{Pendahuluan}

Kehadiran Muhammad Saw menuai banyak perdebatan dan kritik karena menyebut dirinya sebagai utusan Tuhan kepada manusia namun justru berbentuk manusia. Kritik pertama bahkan datang dari orang kafir yang tak rela jika seorang nabi ternyata mempunyai tingkah-laku yang sama seperti manusia

${ }^{1}$ Dosen Universitas Muhammadiyah Prof. Dr. HAMKA, Jakarta. Email: khalifa_158@yahoo.com. 
lainnya. ${ }^{2}$ Namun, hal ini secara umum tidaklah menjadi perdebatan di kalangan muslim. Tindakan kemanusiaan, atau al-af'āl al-jibliyyah, dalam istilah Sulaimān al-Ashqār ternyata banyak yang memang tidak ada kaitannya dengan misi kenabian. ${ }^{3}$ Tindakan seperti makan, minum, tidur, benci, marah dan sebagainya adalah sifat manusia yang secara umum tidak terkait dengan ajaran agama. ${ }^{4}$ Ciri kemanusiaan tertinggi adalah akal. Pemikiran akal inilah yang kemudian disebut sebagai ijtihad. ${ }^{5}$ Namun, yang perlu dipertanyakan berikutnya adalah benarkah bahwa Muhammad pernah berijtihad? Jika benar, apakah ijtihad Nabi menjadi bagian dari ajaran agama?

Dua pertanyaan di atas memerlukan jawaban yang cukup panjang karena akan berimbas bukan hanya dari segi teologi Islam, namun juga yuridis dan filosofis. Untuk itu, kenabian memang bukan hal yang mudah untuk dijelaskan. Ibn Khaldūn (1332-1406) misalnya menilai bahwa nabi adalah mereka yang memiliki jika di luar kemanusiaan pada umumnya dan mendekati malaikat. Bahkan mereka kemudian berinteraksi dengan malaikat dan kemudian menjadi lebih tinggi derajatnya dan mampu berkomunikasi dengan Tuhan. ${ }^{6}$ Pada sisi tertentu nabi adalah manusia biasa namun, pada sisi lain tentu ia lebih dari sekedar manusia biasa. Karena itulah Fazlur Rahman menyebut nabi adalah sebagai extraordinary-man yang memiliki kelebihan luar biasa dihadapan manusia ketika berbicara tentang Tuhan. Merekalah yang bisa menunjukkan secara pasti bahwa Tuhan adalah Tuhan dan setan adalah setan. ${ }^{7}$ Terlebih John L. Esposito menyampaikan bahwa Muhammad adalah intrumen-manusia Tuhan

${ }^{2}$ QS. Al-Furqān [25]: 7.

${ }^{3}$ Muhammad Sulaimān al-Ashqār, Af'āl al-Rasūl wa Dalālatuhā 'ala al-Aḥkām al-Shar'iyah (Kuwait: Maktabah al-Manār al-Islamy, 1976), 219.

${ }^{4}$ Walaupun, jika kemudian dianggap itu datang dari sosok yang memiliki kenabian ia tetap akan menjadi panutan seperti tindak-tanduk dalam keluarga yang muncul sebagaimana manusia pada umumnya. Lihat, Fạ̣d Talāl Salim al-Khalidy "AlManhaj al-Nabawy fì al-Ta‘āmul al-Usrā." College of Basic Education Researches 4 (2007): 79-92.

${ }^{5}$ Karena bagaimanapun ijtihad tidak bisa lepas dari ra'y atau pertimbangan akal manusia yang memungkinkan kesalahan dan kebenaran. Lihat, Mohammad Nazami, "Ijtihad: Takhtī'ah or Taswib." Message of Thaqalayn, A Quarterly Journal of Islamic Studies 10, no. 2 (2009): 74-75; Saim Kayadibi, "Ijtihad by Ra'y: The Main Source Inspiration Behind Istihsān." Islamic Social Science 24, no. 1 (2007) : 76.

6 'Abd al-Rahmān ibn Muhammad ibn Khaldūn, Al-Muqaddimah (Maroko: Dār al-Baidha', 2005), 146-149; Abdul Kabir Husain Solihu, "Revelation and Prophethood in The Islamic Worldview." Journal of Islam in Asia 6, no. 1 (2009) : 170 ; Malak Muhammad Thabit "Abd al-Hamīd, "Mafhūm al-Nubuwah wa al-I'jāz 'Inda alMuslimin." Journal of The Iraqi University 25, no. 1 (2010): 117 ; Hakim 'Abd Nāșir, "Mawqif al-Falsafah al-Muslimin min al-Nubuwah." Adāb al-Kufa 1, (2011): 229.

${ }^{7}$ Fazlur Rahman, Major Themes of the Qur'an (Minneapolis: Bibliotheca Islamica, 1994), 80. 
dalam menyampaikan fiman-Nya sekaligus menjadi model teladan yang harus diikuti orang beriman. ${ }^{8}$ Oleh karena itu, memahami dan mengikuti Nabi Muhammad adalah penting sebagai keimanan dan tindakan keseharian orang Islam yang sebenarnya.

\section{Makna Ijtihad Nabi Muhammad Saw}

Ijtihad bermula dari kata جهـ yakni "ja ha da” yang berarti kesulitan atau kesusahan. Kata ijtihad berasal dari kata الجهد atau al-juhdu yang berarti kemauan dan kesulitan (المشقة), kata ini memiliki derivasi yang sama dengan kata نفعة Mang berarti mencurahkan kemampuan dan daya untuk menghilangkan segala kelemahan demi mencapai suatu tujuan tertentu. ${ }^{9}$ Dengan demikian, respon terhadap kesulitan maupun keinginan manusia terhadap sesuatu bisa dikatakan sebagai ijtihad.

Dalam Islam kata ijtihad selalu dikaitkan dengan penentuan sebuah hukum tertentu. Al-GhazāTi (w. 1111) misalnya mengatakan bahwa ijtihad adalah,

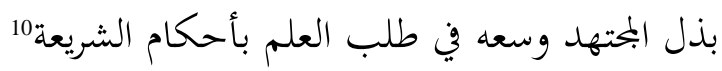

Yakni "mencurahkan segala kemampuan seorang mujtahid dalam mencari sebuah ilmu atau teori dengan hukum syariat." Sejalan dengan hal tersebut alBaidhawi juga mengatakan bahwa ijtihad adalah mencurahkan segala kemampuan dalam mencari hukum-hukum syariat. ${ }^{11}$

Penjelasan-penjelasan di atas menggambarkan bahwa kata ijtihad sering dikaitkan dengan masalah sumber hukum Islam. Al-Qur'an dan hadis adalah sumber hukum Islam yang pasti dan diakui oleh seluruh umat Islam. Namun demikian, jika suatu masalah tidak ditemukan solusinya pada kedua nash tersebut di sinilah fungsi ijtihad itu bermain. Abū Zahrah mengatakan bahwa ijtihad dalam hal ini adalah qiyās. Ia mengutip al-Shafí' 'i yang mengatakan bahwa:

Setiap persoalan pasti ada kepastian hukum dan umat Islam wajib melaksanakannya. Akan tetapi jika tidak ada ketentuan hukumnya yang pasti, maka harus dilakukan pendekatan yang pasti maka

${ }^{8}$ John L. Esposito, Terj. Arif Maftuhi, Islam Warna-warni (Jakarta: Paramadina, 2004), 10; Adis Duderija, "Toward a Methodology of Understanding the Nature and Scope of the Concept of Sunnah.” Arab Law Quarterly 21 (2007): 4.

${ }^{9}$ Wahbah Zuhaili, Ușūl al-Fiqh al-Islamīi (Damaskus: Dār al-Fikr, 1986), 1037; lihat pula Ibn Munzir, Lisān al- 'Arab (Beirut: Dār al-Sin al-'Arab, tth) juz 2, 133-134.

10 'Abd al-Wahhab Khallaf, Masāedir al-Tashri' al-Islam (Kuwait: Dār al-Qalamī, 1972) 7: Saim Kayadibi, "Ijtihad by Ra'y: The Main Source of Inspiration behind Istihsan", The American Journal of Islamic Social Science 24, no 1, (2007) 75.

${ }^{11}$ Al-Baidhawi, Minhājul Wusūul, (Beirut: Muassasah Risalah, 2006) 7. 
harus dicarikan pendekatan yang sah, yakni dengan ijtihad. Dan ijtihad itu adalah qiyās. ${ }^{12}$

Pendapat Imam al-Shāfi'i tersebut menggambarkan peran akal dalam diri manusia untuk menentukan sebuah hukum. Manusia tidak mungkin terlepas dari daya nalar akalnya, bahkan dalam beragama sekalipun. Secara sederhana hal ini juga tergambar dalam hadis tentang ijtihad Muaz yang dibenarkan Rasulullah Saw. ${ }^{13}$

Kata ra'y di atas menunjukkan bagaimana akal menjadi pondasi kuat sebagai sumber dalam menetukan sebuah hukum kala wahyu dalam hal ini alQur'an dan hadis tidak mampu menjawab sebuah persoalan. Namun demikian, pembahasan dalam tulisan ini tidak terpaku dalam soal bagaimana seorang manusia biasa berijtihad, tapi pada seorang Nabi utusan Allah Swt.

Sebagaimana pembahasan pada bab kedua bahwa Nabi adalah manusia biasa sebagaimana manusia umumnya tanpa ada perbedaan. ${ }^{14}$ Sedang makna kenabian itu muncul pada penerimaan risalah atau pesan Allah kepada Nabi untuk manusia umumnya. Namun demikian, kemanusiaan Nabi juga menuntut adanya ijtihad yang dilakukan oleh Nabi dalam menghadapi persoalan baik masalah agama maupun yang lainnya.

\section{Antara yang Setuju dan Tidak Akan Adanya Ijtihad}

Terkait masalah ijtihad dalam diri Nabi para ulama menjadi dua kelompok yakni mereka yang setuju akan adanya ijtihad dan mereka yang tidak setuju terhadap adanya ijtihad pada diri Nabi. ${ }^{15}$ Selain itu ada pula sekelompok lain yang mendiamkan masalah ini. Perbedaan ini tentu menjadin konsekuensi langsung terhadap pertanyaan apakah ijtihad Nabi itu sejajar dengan wahyu atau tidak. ${ }^{16}$ Di sisi lain, karena alasan rasional dan akal manusia, keharusan adanya ijtihad Nabi menjadi penting apalagi terkait dengan masalah keduniaan bahkan peperangan. Namun demikian sebelum membagi antara yang setuju dan

${ }^{12}$ Muhammad Abū Zahrah, Ushūl Fiqih, Terj. Hamdan rasyid dkk. (Jakarta: Pustaka Firdaus, 2005), 336.

${ }^{13}$ Abū Daūd Sulaimān al-Sijistānì (w. 275 H), Sunan Abū Daūd (Beirūt: Maktabah al-'Asriyah, Tth) juz 2, 303.

${ }^{14}$ Al-'Umri mencatat kemanusiaan Nabi bahkan menunjukkan bahwa Nabi juga tidak mengetahui hal ghaib kecuali yang memang telah ditunjukkan Allah kepadanya. Lihat Nādiyat Sharif al-'Umri, Ijtihād al-Rasūl Sallā Allāh 'Alaihi wa Sallam (Beirūt: Muassasah al-Risālah, 1985), 19-20 lihat juga surat Hud [11]: 31 dan al-An'am [6]: 50.

${ }^{15}$ Latifah Abdul Majid dan Mohd Nasir Abdul Majid, "Perkaitan Antara Ayat alKitab dengan ijtihad Rasulullah Saw," Islamiyyat 32 (2010): 65.

${ }^{16}$ Zainuddin MZ, "Kontroversi al-Hadith al-Syarif Wahyu Ilahi Atau Ijtihad Nabi?" Sunan Ampel, Jurnal Profetika 9, no. 1, (2007): 4-5. 
tidak, Sayyid Tanțawi memberikan penjelasan bahwa sebenarnya secara umum para ulama sedangkan adanya ijtihad yang dilakukan Nabi mengenai hal duniawi, namun malasah agama hal tersebutlah yang diperdebatkan bahkan dilarang. ${ }^{17}$

Berkaitan dengan adanya ijtihad pada diri Nabi, Latifah Abdul Majid dan Mohd Nasir Abdul Majid setidaknya memberikan 4 gambaran. Pertama, dari sudut realitas Nabi diperbolehkan melakukan ijtihad secara mutlak karena harus menyelesaikan persoalan baru tanpa harus menunggu wahyu. Kedua, ijtihad secara umum hanya berlaku pada urusan keduniaan semata dan bukan pada urusan syariat. Ketiga, meskipun dalam realitasnya Nabi berijtihad, namun dalam catatan al-Ghazali (w. 1111), ${ }^{18}$ tidak ada naṣ yang menunjukkan keharusan ijtihad itu sendiri. Keempat, secara umum keberadaan ijtihad hanya berlaku setelah Nabi menunggu wahyu terlebih dahulu. ${ }^{19}$

Alasan pembolehan ijtihad yang dilakukan oleh Nabi bisa dilihat dari dua aspek, pertama aspek nash baik al-Qur'an maupun hadis kedua adalah alasan rasional. Dalam kaitan nas al-Qur'an, Allah menyebutkan masalah tawanan perang yang disepakati Nabi setelah bermusyawarah dengan para Sahabat. ${ }^{20}$ Teguran yang disampaikan Allah Swt kepada Rasulullah nampak jelas menjadi pedoman akan adanya ijtihad yang dilakukan oleh Nabi. Namun demikian, al'Umri menyatakan bahwa adanya kesalahan dalam ijtihad Nabi adalah isyarat yang jelas akan adanya pemikiran manusia yang dalam kecerdasan apapun bisa menimbulkan kesalahan dan inilah bedanya dengan wahyu. ${ }^{21}$

Harus pula dipahami bahwa dalam hal permusyawaratan ini adalah pula perintah Allah dan bukan sekedar keinginan Nabi. ${ }^{22}$ Perintah وشاورهم في الامر juga mengisyaratkan adanya permusyawaratan terhadap persoalan yang dihadapi Nabi. Dengan demikian, Nabi diperbolehkan bahkan diperintahkan untuk berijtihad dalam sebuah peroslana yang memang tidak dijelaskan oleh wahyu. ${ }^{23}$

${ }^{17}$ M. Sayyid Tantawī, Konsep Ijtihad Dalam Hukum Syarak. Terj. Safri Mahayedin, (Kuala Lumpur: Institute Terjemahan Negara Malaysia, Cet. 2 2009), 44.

${ }^{18}$ Abū Hamīd Muhammad al-Ghazāii, al-Mushtashfă min 'Ilmi al-'Usūul (Kairo: Muassasah al-Halabi, Tth), 355.

${ }^{19}$ Latifah Abdul Majid dan Mohd Nasir Abdul Majid, "Perkaitan Antara Ayat alKitab dengan ijtihad Rasulullah Saw," Islamiyyat 32 (2010): 66.

${ }^{20}$ Persoalan terkait musyawarah Nabi dengan Sahabat dalam hal peperangan lihat lebih lanjut, Ahmad Maṭar Khadir, "Mushāwarāt al-Rasūl Saw Li Aṣhābihi fì alGhazawāt." Jurnal Research Diyala Unversity (2009): 74-86. Lihat Qs. Al-Anfal [8]: 6768.

${ }^{21}$ Nādiyat Sharif al-'Umri, Ijtihād al-Rasūl Salla Allāh 'Alaihi wa Sallam, 47-48.

${ }^{22}$ Lihat Âli Imrān [3]: 159.

${ }^{23}$ Nādiyat Sharif al-'Umri, Ijtihād al-Rasūl Salla Allāh 'Alaihi wa Sallam, 55-56. 
Adapun dalam hadis Nabi, Qādi 'Iyād memberikan penjelasan dalam kitabnya al-Shifá' tentang beberapa riwayat terkait kesalahan Nabi dalam memberikan saran terhadap para petani kurma. ${ }^{24}$ Nabi mengatakan,

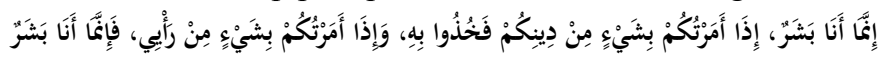

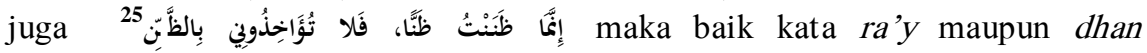
mengindikasikan perilaku ijtihad Nabi.

Dalam argumentasi rasional jelas bahwa manusia tidak ciptakan seperti robot namun ia memiliki akal untuk menentukan pilihan dan menyelsaikan persoalan. Hal ini berlaku bagi setiap manusia tak terkecuali Nabi sekalipun. Bahkan al-Amidi mengatakan bahwa andai Nabi tidak melakukan ijtihad sedang umatnya diperbolehkan, hal ini malah menggambarkan betapa Nabi tidak lebih cerdas dari umatnya. ${ }^{26}$ Mengapa demikian? Karena ijtihad diperlukan kecerdasan akal sedang mereka yang tidak pernah melakukan ijtihad berarti tidak memiliki kecerdasan akal.

Namun demikian adanya teguran terhadap kesalahan Nabi dalam berijtihad menunjukkan bahwa posisi ijtihad tidak bisa disamakan dengan wahyu. ijtihad hanya menunjukkan bahwa kedudukan Nabi tidaklah berbeda dengan manusia biasa dalam berfikir sedang perbedaan terletak pada wahyu yang diberikan sebagai pembetulah Allah kepada kesalahan Nabi.

Di samping adanya persetujuan ulama terhadap ijtihad yang dilakukan Nabi, ada pula ulama yang tidak sepakat dengan adanya ijtihad tersebut. Mereka adalah Ibn Hazm (w. 1064), al-Maturidi (w. 944), Abu al-Mansur dari golongan al-As'ariyah dan al-Jubbai (w. 915) dari golongan Muktazilah yang mengatakan bahwa ijtihad tidak diperbolehkan bagi para Nabi bahkan jika tidak ada nas sekalipun. ${ }^{27} \mathrm{Hal}$ ini dilandaskan pada ayat berikut,

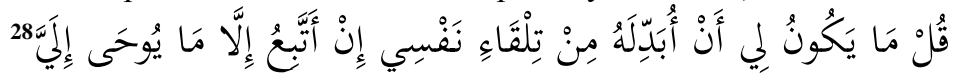

Bahwa memang tidak patut bagi nabi untuk mengikuti sesuatu selain wahyu yang diberikan kepadanya. Sehingga ayat ini menegasikan adanya ijtihad bagi seorang Nabi. Adapun ayat 67-68 Surat al-Anfal di atas, Ibn Hazm

${ }^{24}$ Al-Qaḍi 'Iyad, al-Shifa' (Kairo: al-Matba'ah al-Azhariyah, 1327 H), juz 4, 265 : Nādiyat Sharif al-'Umri, Ijtihād al-Rasūl Șallā Allāh 'Alaihi wa Sallam, 41-43.

${ }^{25}$ Muslim ibn Hajjāj al-Nisaburi, Sahịh Muslim (Beirut: Dar al-Ihya' al-Turath, Tth) juz 4, 1835.

${ }^{26}$ 'Ali Shaifuddin al-Amidi, al-Ịhkām fì 'Ușūl al-Aḥkām (Beirūt: Dār al-Kutub al-'Ilmiyyah), 147.

${ }^{27}$ Latifah Abdul Majid dan Mohd Nasir Abdul Majid, "Perkaitan Antara Ayat alKitab dengan ijtihad Rasulullah Saw," 71-72

${ }^{28}$ Yūnus [10]: 15. 
menjelaskan bahwa pada hakekatnya Rasulullah pun memiliki pilihan yang sama seperti Sahabat. Dalam hal ini Rasulullah lebih memilih pendapat Sahabat, karena itulah Rasul ditegur bukan karena pendapatnya melainkan karena kecenderungannya untuk mengikuti Sahabatnya itu. ${ }^{29}$

\section{Model Ijtihad Nabi}

Kemanusiaan Nabi yang berbentuk ijtihad memunculkan banyak varian yang tergambar dalam perilaku hidupnya. Al-'Umri mencatat setidaknya ada lima bentuk ijtihad yang dilakukan Nabi, yakni dalam bentuk prasangka, larangan, keinginan, perintah dan doa. ${ }^{30}$ Namun demikian, tidak pula menutup adanya bentuk ijtihad yang lain karena memang Nabi makan sebagaimana manusia lainnya, tidur sebagaimana manusia lainnya bahkan lupa sebagaimana manusia lainnya. ${ }^{31}$

Gambaran ijtihad nabi setidaknya menjawab beberapa pertanyaan berikut:

a. Tentang keberadaan ijtihad. Mulai keberadaan ijtihad Nabi apakah kemudian memungkinkan Nabi untuk melakukan sesuatu tanpa ijin kepada Allah, lalu materi ijtihad apakah hanya terkait persoalah dunia ataukah ibadah, apakah terkait pula masalah hal ghaib ataukah tidak.

b. Tentang benar tidaknya ijtihad. Apakah ijtihad Nabi selalu benar atau tidak, kemudian jika memang salah apakah pernah ijtihad Nabi salah dalam hal agama.

c. Tentang pembetulan. Apakah tidak kesalahan Nabi selalu dibenarkan lewat wahyu Allah atau adakah yang tidak. Dan jika tidak, apakah yang tidak terdapat pembenaran lewat wahyu itu terkait dengan agama atau dunia semata? ${ }^{32}$

d. Tentang respon Sahabat. Apakah Sahabat selalu melaksanakan setiap ijtihad yang diajukan Nabi ataukah mempertimbangkannya atau bahkan menolaknya?

${ }^{29}$ Abū Muhammad ibn Hazm al-Andalūsì al-Zahirī, al-Ihkām fì Usūul al-Aḥām (Kairo: Sa'adah, Tth), 698-699.

${ }^{30}$ Nādiyat Sharif al-'Umri, Ijtihàd al-Rasūl Salla Allāh 'Alaihi wa Sallam, 57.

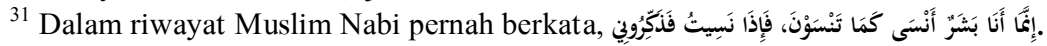
Lihat, Muslim ibn al-Hajjaj, Musnad al-Sahịh (Beirut: Dar al-Ihya', Tth), juz 1, 400.

${ }^{32}$ Dalam penggambaran ijtihad Nabi al-'Umry tidak menyebut tentang respon Sahabat sebagai bagian dari wawasan yang bisa didapat. Menurut penulis hal ini mungkin karena memang al-'Umri terfokus para perilaku Nabi. lihat, Nādiyat Sharif al'Umri, Ijtihād al-Rasūl Sallā Allāh 'Alaihi wa Sallam, 57-59. 


\section{Ijtihad Nabi yang Dibenarkan dan Disalahkan oleh Wahyu}

Ijtihad Nabi yang dibenarkan oleh wahyu diantaranya adalah adanya keinginan Nabi untuk memindahkan arah kiblat dari Baitul Maqdis ke Ka'bah sebagaimana riwayat berikut:

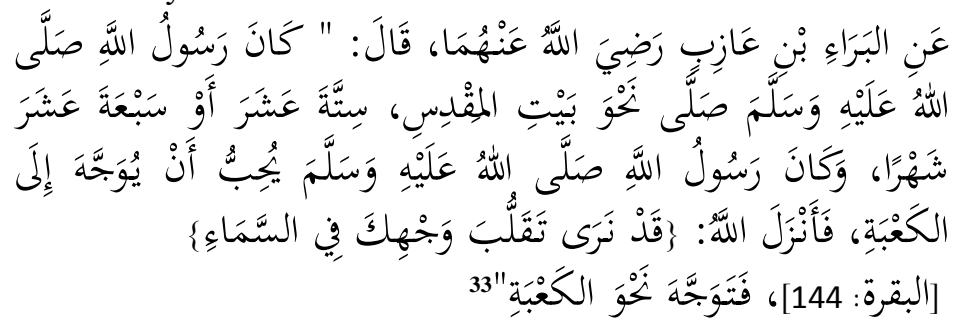

"Rasulullah shalat menghadap ke Baitul Maqdis selama 16/17 bulan. Namun, Nabi lebih menyukai untuk mengahadap ke ka'bah. Karenanya turunlah ayat, 'Sungguh kami (Allah) sering melihatmu (Muhammad) menengadahkan wajahmu ke langit. ${ }^{34}$, Maka setelah itu Rasul shalat mengahadap ka'bah."

Hadis di atas menggambarkan bagaimana ijtihad yang telah lama menginginkan untuk menghadap kiblat ke Ka'bah kemudian mendapat jawaban dari Allah berupa perintah untuk memindahkan kiblat. Al-'Umri memasukkan ijtihad ini ke dalam ijtihad berbentuk harapan atau keinginan. ${ }^{35} \mathrm{Hal}$ ini menjelaskan bahwa ijtihad yang dilakukan Nabi dalam hal agama tidak berbentuk tindakan atau perintah Nabi sendiri karena agama memang murni perintah dan bukan pendapat Muhammad pribadi sebagaimana dijelaskan dalam surat Yunus ayat 50 sebelumnya. Selain itu pembenaran atas ijtihad Nabi memang bagian dari pemikiran Nabi yang menganggap bahwa Ka'bah lebih cocok dari Baitul Maqdis. Peristiwa ini juga menggambarkan bagaimana pembelajaran Islam kepada Nabi dan para Sahabat kala itu untuk menyingkirkan kesalahan agama Yahudi dari Islam. ${ }^{36}$

Ijtihad Nabi yang disalahkan atau ditegur oleh wahyu di antaranya adalah ketika Nabi dan para Sahabat bermusyawarah tentang tawanan perang Badr. Nabi kemudian menanyakan kepada Abu Bakar tentang pendapatnya mengenai tawanan itu. Abu Bakar menjawab, "Ya Rasulullah, mereka dulu

${ }^{33}$ Muhammad ibn Ismail al-Bukhari, Musnad al-Sahih, (Kairo: Dar al-Tauq alNajah, 1422 H) juz 1, 88.

${ }^{34}$ Maksudnya yakni menunggu wahyu.

${ }^{35}$ Nādiyat Sharif al-'Umri, Ijtihād al-Rasūl Salla Allāh 'Alaihi wa Sallam, 7178.

${ }^{36} \mathrm{Abu}$ 'Abdullah al-Qurtubi (w. 671), al-Jamī' al-Ahkām al-Qurān, (Kairo: Dar al-Kutub, 1964 M), juz 2, 161 
adalah bagian dari kita dan keluarga kita. Apakah tidak lebih baik kita mengambil uang tebusan agar kita menjadi kuat terhadap kaum kafir. Maka, semoga allah pun memberikan hidayah kepada mereka untuk masuk Islam." Nabi pun bertanya hal yang sama kepada Umar, lalu Umar menjawab, "Tidak ya Rasulullah, aku tidak sepakat dengan pendapat Abu Bakar, mereka (tawanan) itu adalah pimpinan kaum kafir, maka hendaklah mereka dibunuh."

Saat itu Nabi agaknya lebih cenderung kepada pendapat Abu Bakar. Namun tiba-tiba Nabi dan Abu Bakar menangis, lalu Umar pun bertanya, " $Y a$ Rasul apa yang membuatmu dan sahabatmu menangis?' Nabi menjawab, "Aku menangis karena aku setuju untuk meminta tebusan dari tawanan ini." Kemudian turunlah ayat al-Qur'an, “Tidak patut, bagi seorang Nabi mempunyai tawanan sebelum ia dapat melumpuhkan musuhnya di muka bumi. Kamu menghendaki harta benda duniawiyah sedangkan Allah menghendaki (pahala) akhirat (untukmu)..." 37 Akhirnya tawanan itu pun dibunuh sebagaimana perintah Allah. ${ }^{38}$

Dengan demikian dari hadis di atas secara sederhana memperlihatkan bagaimana ijtihad Nabi yang jika keliru tentu akan ditegur atau dibenarkan oleh Allah lewat wahyu. Namun demikian tentu tidak semua wahyu disampaikan kepada Nabi untuk memberikan teguran buat beliau melainkan pula untuk para Sahabat yang ikut menjadi pertimbangan Nabi. ${ }^{39}$

\section{Ijtihad Nabi sebagai Respon atas Sahabat}

Ada pula riwayat tentang siasat perang yang disampaikan Nabi kepada para Sahabat namun ternyata ada Sahabat yang menganggap bahwa siasat itu salah dan ia pun menawarkan siasat baru bagi Nabi. Kejadian ini terjadi pada saat perang Badr.

Pada waktu perang Badr, Nabi Muhammad mendahului orang Quraisy menuju mata air. Kemudian al-Hubab ibn Munzir menemui Nabi dan berkata, "Ya Rasulullah, apakah anda sengaja memilih posisi ini? Ataukah posisi ini telah dipilihkan Allah sehingga kita tidak berpindah? Ataukah ini hanya tipu daya dalam peperangan?' Nabi menjawab, "Hal ini hanyalah taktik dan tipu daya peperangan." Selanjutnya al-Hubab menyarankan, "Ya Rasul, posisi ini menurutku kurang strategis. Lebih baik kita menyuruh beberapa orang untuk menjaga sumber air dan kita buat telaga yang mengalir dari air ini. Sehingga,

\footnotetext{
${ }^{37}$ Al-Anfal [8]: 67-68.

${ }^{38}$ Hadis lebih lengkap lihat. Sahị Muslim, juz 3, 1383.

${ }^{39}$ Bisa pula lihat kisah lain tentang turunnya awal surah al-Naba.
} 
kita bisa berperang tanpa kehausan, sedangkan musuh pasti kehausan." Akhirnya hal ini pun disetujui oleh Nabi. ${ }^{40}$

Hadis di atas mengisyaratkan sebuah respon Sahabat kepada Nabi yang ternyata jika ada sebuah saran Nabi dan pada saat yang sama Sahabat memiliki saran lain yang berbeda maka ia pun mengutarakannya pada Nabi. Adapula isyarat yang menunjukkan bahwa tidak selamanya perintah Nabi itu dilakukan dengan serta merta oleh Sahabat. Namun, jika Nabi jelaskan bahwa perintah tersebut berasal dari Allah, maka pasti Sahabat langsung mengerjakannya.

\section{Ijtihad Nabi Yang Salah Namun Tidak Dibenarkan Dengan Wahyu}

Terkait masalah ijtihad Nabi yang keliru namun tidak dibenarkan dengan adanya wahyu Allah adalah tentang saran Nabi kepada para petani Kurma di Madinah. Diriwayatkan dalam Șahih Muslim bahwa suatu ketika Nabi pernah pergi ke Madinah dan melihat para petani sedang melakukan penyerbukan kurma. Lalu Nabi berkata, “Apa yang kalian lakukan itu?' Mereka menjawab, “Kami telah terbiasa melakukannya." Nabi pun memberi saran, “Jika kalian tidak melakukan itu, pasti akan lebih baik." Akhirnya para petani kurma pun tidak lagi melakukannya, namun ternyata panennya berkurang. Akhirnya mereka pun lapor ke Nabi dan kemudian Nabi berkata, "Sungguh aku hanya manusia biasa. Jika aku perintahkan kalian tentang agama kalian maka taatilah, namun jika aku perintahkan tentang suatu hal dari pendapatku, maka sungguh aku pun hanya manusia biasa." ${ }^{41}$

Dalam riwayat lain Nabi mengatakan, "Jika hal itu bermanfaat maka lakukanlah, sungguh aku hanya memberikan saran dengan prasangkaku, maka janganlah ikuti prasangkaku. Namun, jika aku ajarkan kalian sesuatu tentang Allah, maka terimalah. Karena sungguh aku tidak akan pernah berbohong tentang Allah $S$ wt." 42 al-'Umri juga memberikan riwayat lain tentang jawaban Nabi yakni, "Sungguh jika ada suatu hal terkait dengan agama kalian maka akulah yang lebih tahu. Namun jika terkait masalah dunia kalian maka kalianlah yang lebih tahu." ${ }^{43}$ Dan juga, "Sungguh kalian lebih mengetahui tentang dunia kalian." 44

Peristiwa di atas banyak menyita perhatian para studi hadis terkait dengan ijtihad Nabi yang keliru. Sebagaimana pada bab sebelumnya bahwa

${ }^{40}$ Abdul Jalil Isa Abu al-Nasr, Ijtihad Rasulullah Saw. terj. Wawan Djunaedi. (Jakarta: Pustaka Azzam, 2001) 190-192

${ }^{41}$ Muslim ibn Hajjaj, Sahih Muslim, juz 3, 1745.

${ }^{42}$ Muslim ibn Hajjaj, Sahih Muslim.

${ }^{43}$ Nādiyat Sharif al-'Umri, Ijtihād al-Rasūl, 107.

${ }^{44}$ Nādiyat Sharif al-'Umri, Ijtihād al-Rasūl, 108. 
Muhammad adalah manusia biasa yang sama sebagaimana manusia lainnya, sebenarnya kesalahan ini adalah hal wajar yang biasa saja. Namun, jika dilihat sebagai kepribadian kenabian yang ada pada diri Muhammad tentu menjadi problem tersendiri.

Al-Nawawi mengatakan bahwa pendapat Nabi yang terkait dengan masalah kehidupan dunia sebagaimana di atas bukanlah tanggungjawab dan materi dari kenabian Muhammad Saw. ${ }^{45}$ Selain itu Nabi dalam sejarahnya memang tidak pernah belajar tentang pertanian. Sehingga, ketidaktahuan Nabi terahadap penyerbukan pohon kurma adalah menjadi sebuah kewajaran. Selain itu ibn Khaldun mengatakan bahwa adapun perkataan Nabi terkait dengan kehidupan dunia seperti pertanian dan pengobatan adalah berdasarkan pengalaman dan pengamatan yang sehari-hari ia lakukan, tent unya tanpa adanya wahyu di sana. $^{46}$

Menutup pada poin berbagai model ijtihad dan dampaknya di atas dapat diambil beberapa benang merah menarik sebagai berikut. Pertama, bahwa Nabi memang manusia biasa yang tidak terlepas dari sisi kemanusia seperti ijtihad, kesalahan dan juga kritik. Sebaliknya, hal ini juga menunjukkan bahwa Nabi bukanlah wujud Tuhan dalam bentuk manusia suci tanpa kesalahan. Kedua, proses penerimaan hadis dari Sahabat tidak sekedar wujud ketaatan buta, namun juga diproses lewat logika yang memungkinkan interfensi Sahabat di dalam pendapat Nabi dalam hadis itu sendiri. Ketiga, kemaksuman Nabi bukanlah pada kesucian Nabi dari kesalahan, namun penjagaan terhadap kesalahan Nabi yang jika itu terjadi dan berimbas dalam misi kenabiannya, maka Wahyu Allah pun ikut interfensi dalam pembetulan ijtihad tersebut.

Untuk masalah ketiga di atas, maka pembahasan wahyu dalam kaitannya dengan hadis menjadi perlu didudukkan dengan jelas. Hal ini agar kemudian dapat dipahami manakah yang kemudian ijtihad Nabi dan manakah hadis Nabi yang sebenarnya bagian dari wahyu Allah itu sendiri.

\section{Wahyu dalam Ijtihad Seorang Nabi}

Hadis yang paling mungkin dianggap sebagai wahyu adalah hadis qudsi. Hadis jenis ini hampir tidak akan penah disebut sebagai ijtihad nabi. Karena memang hadis jenis ini memiliki indikasi bahwa yang berkepentingan dalam isi atau objek matan hadisnya adalah Allah sebagai sumber wahyu itu sendiri. Makna hadis qudsi sendiri diambil dari kata al-quds yang berarti suci, dimana yang dimaksud tentu adalah Allah Swt. Untuk itu, hadis qudsi adalah jenis

\footnotetext{
${ }^{45}$ Nādiyat Sharif al-'Umri, Ijtihād al-Rasūl, 109.

${ }^{46}$ Nādiyat Sharif al-'Umri, Ijtihād al-Rasūl, 109-110.
} 
hadis yang menunjukkan bahwa Rasulullah adalah yang memiliki otoritas dalam pemilihan kata sedang isi atau materi dari hadis tersebut memiliki korelasi terhadap kesucian Allah. Atau, segalala sesuatu yang dikabarkan Allah kepada para nabi-Nya, maka kemudian kabar itupun disampaikan kepada manusia dengan ungkapan dari nabi sendiri. Hal ini tentu tidak sama dengan Alquran yang lafadnya pun dari Allah. ${ }^{47}$

Setidaknya sisi kesucian dari hadis qudsi memiliki dua model berbeda. Pertama adalah berisi tentang segala kegiatan atau pekerjaan yang dilakukan oleh Allah dan kedua adalah tentang segala yang dilakukan oleh Allah. Untuk yang pertama bisa terlihat dari beberapa kalimat yang sering digunakan oleh

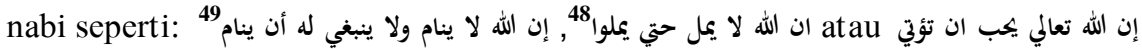
Hadis- hadis tersebut mengindikasikan tindakan Allah dengan ungkapan nabi bahwa Allah melakukan ini dan itu. Karena tindakan ini adalah tidakan yang dilakukan oleh Allah Yang Maha Suci, hadis jenis ini pun digolongkan pada hadis qudsi. ${ }^{51}$

Sedangkan untuk hadis yang menyatakan ungkapan atau perkataan Allah

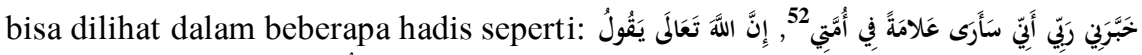

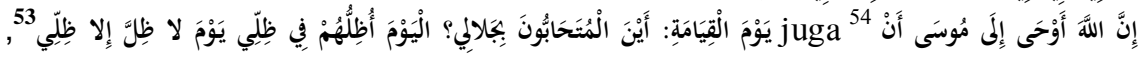

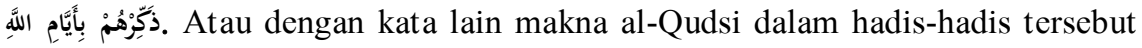
adalah isi dari ungkapan atau perkataan Allah didalamnya yang memuat bahwa Allah mengatakan ini dan itu.

Tentunya, baik hadis qudsi yang mengungkapkan perkerjaan maupun perkataan Allah ini tidak bisa dianggap sebagai ijtihad Nabi. Namun, sebagaimana difahami awal bahwa hadis qudsi adalah isinya dari Allah atau mengenai tindakan Allah namun lafadnya muncul dari Nabi. Untuk itu, sisi kemanusaan atau ijtihad Muhammad dalam hal ini pun tetap berlaku yakni pada

47 Imān Khalifah Hamīd, "Al-Mandūmāt al-Khịāabiyah fì al-Ahādith alQudsiyah.” Al-Tarbiyah wa al-'Ilm 13, no. 4 (2006), 229.

${ }^{48}$ Muhammad ibn Hibbān (w. 354), Sahịh ibn Hibbān, (Beirūt: Muassasah Risālah, 1993), juz 2, 67.

${ }^{49}$ Muslim ibn Hajjaj, Sahịh Muslim, juz 1, 162; Lihat juga Muhammad ibn Hibbān, Sahịh Ibn Hibbān, juz 1. 499. juz 3, 1040

${ }^{50}$ Áù Sa'id ibn al-'Araby, Mu'jam ibn al-'Araby (Saudi: Dār ibn Jauzi, 1997)

51 Imān Khalifah Ḥamìd, "Al-Mandūmāt al-Khịtābiyah fî al-Ahādith alQudsiyah." 231-232.

${ }_{52}$ Muslim ibn hajjaj, Sahih Mustim, juz 1, 351.

${ }^{53}$ Abū Muhammad Abdullah al-Darimīi, Musnad al-Darīmì, (Saudi: Dār alMughni, 2000) juz 3, 1814.

${ }^{54}$ Abū Bakr Aḥmad ibn Ibrahim al-Isma'ili, al-Mu'jam fì Asāmi Shaikh Abi Bakr al-Ismā'ily, (Madinah: Maktabah al-'Ulūm wa al-Hukm, 1410 H) juz 3, 792. 
pola pemilihan kalimat atau lafaz agar mudah difahami oleh manusia pada umumnya. $^{55}$

Jika kemudian hadis dimaknai sebagai segala yang datang dari Nabi baik berupa perkataan, perbuatan dan ketetapannya, lalu apakah ia juga dianggap sebagai wahyu? Hal ini tentu memerlukan untuk kembali melihat bagaimana penafsiran para ulama terhadap surat al-Najm ayat 3 dan 4. Penafsiran ini setidaknya menentukan apakah segala yang disampaikan Nabi sebagai wahyu ataukah ijtihad Nabi sendiri.

Ibn Katsir dalam tafsirnya mengatakan bahwa maksud "Nabi tidak pernah berbicara menurut hawa nafsunya" adalah bahwa memang Nabi memang menyampaikan segala yang diperintahkan tanpa ada pengurangan dan ada tambahan di dalamnya. Pendapat mengindikasikan bahwa memang ungkapan Nabi bukanlah ijtihad melainkan wahyu. Ibn Katsir setidaknya menyampaikan beberapa riwayat berikut:

"Abdullah ibn Umar pernah bercerita, "Dulu aku mencatat segala yang aku dengar dari Nabi Saw. karena aku ingin menghafalnya. Namun, orang Quraisy melarangku dan berkata, 'Kenapa kau mencatat segala yang datang dari Nabi padahal ia adalah manusia biasa yang kadang berkata dengan emosionalnya!' Maka aku laporkan hal tersebut kepada Nabi dan beliau berkata, 'Catatlah, demi Allah yang nyawaku ada dalam genggamannya. Tidaklah datang dariku kecuali kebenaran." "56

Adapun dalam riwayat lain Nabi juga mengungkapkan bahwa, "Sungguh segala yang aku beritahukan kepadamu adalah dari Allah semata dan tidak ada keraguan di dalamnya."57

Penyataan di atas memang mengindikasikan bahwa ucapan Nabi Saw adalah memang kebenaran. Persoalannya adalah apakah kebenaran itu bagian dari wahyu? Ataukah segala yang dari Nabi namun terkait dengan agama semata? Setidaknya dapat difahami bahwa yang dialami oleh Ibn Umar diatas adalah penentangan dari seorang Quraish yang pada saat yang sama Nabi ingin menunjukan bahwa apa yang datang darinya pastilah kebenaran. Namun apakah makna haq di atas berarti al-Quran atau hadis juga?

${ }^{55}$ Dalam hal ini Nabi memiliki otoritas untuk menentukan bagaimana pola kalimat agar mudah dan sesuai dengan lawan bicara Nabi sendiri. Sehingga, kemampuan Nabi dalam berbahasa pun menjadi penentunya. Lihat kesimpulan tesis Marwah Ibrahim Sya'ban, "al-Ahādith al-Qudsiyah: Dirāsah Balaghiyah." 2007, Fakultas Adab, Universitas Ghaza, 194-195.

${ }^{56}$ Ibn Katsir (w. 774 H), Tafsìr al-Qurān al- 'Azìm (Kairo: Dar al-Tayiibah, 1999) juz 7,443 .

${ }^{57}$ Ibn Katsir, Tafsìr al-Qurān al-'Azìm, juz 7, 443. 
Setidaknya Abū Hafz menyatakan bahwa kata ينطق pada surat al-Najm tersebut memang memiliki dua dhamir yang berbeda. Pertama, pertama secara dhāhir tentu dhamimya adalah Nabi Muhammad Saw. Kedua, namun harus difahami bahwa objek dari pembicaraan ini adalah al-Qur'an. Hal ini sejalan ينطق dengan kata haq yang ada pada hadis di atas dan juga diulang perkataan tersebut dalam al-Qur'an yakni هذا كِنَابُنَا يَنْقُ عَلَيْكُم بالحقى ${ }^{58}$ Jadi, dhamir dari kata tersebut bukanlah Nabi sendiri melainkan adalah Alquran. ${ }^{59}$

Sejalan dengan hal ini sebenarnya sudah disampaikan pada pembahasan sebelumnya bahwa adalah jika Nabi menyampaikan hal terkait dengan Allah maka pastilah hal itu benar. Namun, jika yang disampaikan adalah hal lain selain Allah atau ajarannya maka hal itu bisa jadi datang dari ijtihad Nabi sendiri. Setidaknya Imam Tabari memberikan alasan sebuah riwayat dari Sahabat yang juga memiliki pendapat ini yakni dari Qatādah. Dalam hal ini Qatādah memberikan pernyataan bahwa ayat 3 dan 4 dari Surat al-Najm tersebut bermakna bahwa Allah memberikan wahyu kepada Jibril dan Jibril memberikannya kepada Muhammad Saw. atau dengan kata lain 'tidaklah alQur'an itu perkataan dari hawa nafsu Muhammad melainkan ia adalah wahyu dari Allah yang diberikan kepadanya. ${ }^{60}$

Dengan demikian kesimpulan dari penafsiran para ulama tentang makna dari pembacaraan Nabi berupa wahyu dalam Q.S. al-Najm tersebut adalah alQur'an. Sehingga, mengenai hadis maka hal ini bisa saja ia menjadi wahyu jika memang terkait dengan ketuhanan dan segala ajarannya. Namun jika terkait soal keduniaan dan kehidupan sehari-hari sebagaimana kebutuhan manusia biasa maka hal itu bisa berarti ijtihad Nabi.

\section{Respon Sahabat atas Ijtihad Nabi}

Setiap umat muslim akan memahami bahwa pemahaman dan pengetahuan Sahabat tentang hadis adalah yang paling baik. Setidaknya hal ini bisa dilihat dari 3 hal. Pertama, Sahabat adalah orang yang paling dekat hidupnya dengan Nabi. Kedua, Sahabat adalah lawan bicara Nabi. Ketiga, selain masalah agama yang disampaikan oleh Nabi, hadis merupakan solusi dari berbagai persoalan kehidupan Sahabat. Karenanya, memahami ijtihad Nabi yang lebih relevan tentu melihat bagaimana pandangan dan respon Sahabat terhadap kenabian Muhammad dan pendapat (ijtihad) beliau di dalamnya.

${ }^{58}$ Al-Jāsiyah [45]: 29.

${ }^{59}$ Abu Hafz Siraj al-Dīn al-Dimasqy (w. 775 H), al-Lubāb fí 'Ulūm al-Kitāb (Beirūt: Dār al-Kutub al-'Imiyyah, 1997) juz 18, 107.

${ }^{60}$ Muhammad ibn Jarir al-Tabari, Jàmi' al-Bayān fí Ta'wil al-Qurān (Riyadh: Muassasah al-Risalah, 2000) juz 22, 497-498. 
Sebagaimana difahami Sahabat adalah mereka yang dekat dengan Nabi. Kedekatan ini memiliki persepsi berbeda pada beberapa ulama. Ahmad Ibn Hanbal (w. 241 H), sebagaimana catatan Khatib al-Bagdady (w. 463 H) menyampaikan bahwa Sahabat adalah,

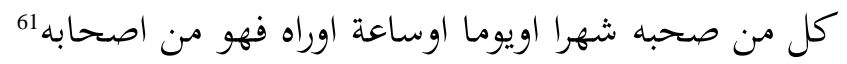

Yakni bahwa sahabat adalah orang yang pernah bertemu dengan Nabi Saw., baik sebulan, sehari ataupun satu waktu saja. Al-Bagdady menyampaikan pula bahwa Imam Bukhari menambahkan dengan syarat bahwa mereka adalah kaum muslim. ${ }^{62}$

Kondisi Sahabat secara umum digambarkan oleh Nabi sebagai generasi terbaik dalam Islam. Sebagaimana ungkapan hadis bahwa Nabi Saw., mengatakan sebaik-baik zaman adalah zaman Nabi kemudian berikutnya dan berikutnya. Pernyataan ini tentu membuktikan bagaimana sifat para Sahabat dihadapan Nabi. Dimana, para Sahabat sangat dipercaya Nabi sebagai kaum yang terbaik yang Nabi lihat. Terlebih Nuruddin 'Itr menyatakan bahwa Nabi Muhammad menerima dan mempercayai pernyataan siapapun yang datang kepada beliau selama ia beriman kepada Allah dan rasul-Nya. ${ }^{63}$

Pandangan Sahabat terhadap kenabian Muhammad Saw bisa pula dilihat dari cara para Sahabat mendapatkan hadis. 'Umar pernah mengungkapkan bahwa ia dan salah seorang Sahabat dari Bani Umayyah ibn Yazin bergiliran dalam mendapatkan informasi dari Nabi. Kegiatan ini dilakukan 'Umar dengan cara jika sahabatnya tadi pergi ke Nabi maka 'Umar cukup mendengar dari sahabatnya tersebut, namun pada lain hari 'Umarlah yang datang dan kemudian ia memberitahukan informasi baik wahyu maupun yang lain kepada temannya tersebut. ${ }^{64}$

Pandangan Sahabat terhadap kenabian juga terlihat bagaimana ketaatan Sahabat pada Nabi Muhammad. Ketaatan ini kadang tidak sekedar pada hal yang diperintahkan bahkan juga pada hal yang sekedar pernah dilakukan oleh Nabi. Terlebih keikutsertaan ini bahkan tidak disertai oleh Sahabat tentang manfaat keikutsertaan tersebut. Hal ini pernah terjadi pula pada 'Umar ketika ia

${ }^{61}$ Khatib al-Bagdady, Kitāb al-Kifāyah fí 'Ilm al-Riwāyah (Beirut: Dār al-Kutub, 1988), 51; lihat juga Ibn Atsir, Asād al-Ghābah fí Ma'rifat al-Sậābah (Kairo: Dār Kutūb al-'Ilmiyyah, 1994) 16.

${ }_{62}$ Khatib al-Bagdādy, Kitāb al-Kifāyah fì 'Ilm al-Riwāyah, 15.

${ }^{63}$ Nuruddin 'Itr, 'Ulūm al-Hadis, 107-108. Hal ini juga dicontohkan Nabi ketika dalam peristiwa penerimaan Nabi terhadap kabar dari orang Arab Badui yang mengaku melihat hilal bulan Ramadhan sedang Sahabat yang lain tidak. Lihat, Abu Abdurrahman al-Nasa'i (w. 303), Sunan al-Nasa'i (Beirut: Muassasah Risalah, 2001) juz 3, 97.

${ }^{64}$ Lihat Muhammad ibn Ismail al-Bukhari, Sạhị al-Bukhari (Riyādh: Dār alTauq al-Najjah, 1422 H) juz 1, 39. 
akan mencium Hajar Aswad. Ia berkata, "Sungguh, seandainya aku tidak melihat Muhammad menciummu dan menyentuhmu nisacaya aku tidak akan melakukannya." ${ }^{\circ 5}$

Selain itu ada pula riwayat Ibn 'Umar yang menceritakan tentang cincin emas yang dipakai Nabi. Suatu hari Nabi pernah memakai cincin emas, maka semua orang pun mengikutinya. Akan tetapi Nabi kemudian hari mengungkapkan, "Aku telah memakai cincin emas, kemudian aku pun melepaskannya." Maka Ibn 'Umar berkata, "Sungguh aku tidak akan pernah lagi memakai cincin emas dan seluruh manusia pun melepasnya."66

Ada pula pernyataan dari 'Ali bahwa ketika lewat jenazah di depan Nabi, beliau pun berdiri dan semua orang pun akhirnya ikut berdiri. Kemudian Nabi pun duduk dan yang lain pun demikian. ${ }^{67}$

Beberapa riwayat di atas menyebutkan bagaimana ketaatan para Sahabat yang begitu tinggi meskipun tanpa adanya perintah untuk mengikutinya. Namun demikian secara rasional al-Amidy memberikan pendapat setidaknya ada 4 alasan mengapa Nabi menjadi model bagi para Sahabat. Pertama, perbuatan Nabi mengandung hal yang wajib dan yang tidak dalam mengikutinya, namun mengikuti yang tidak wajib itu dianggap lebih menentramkan hati dari pada meninggalkannya. Kedua, kenabian adalah kedudukan yang mulia. Dalam arti, mengikutinya pun berarti mengagungkan dan menghormatinya. Ketiga, perbuatan Nabi dianggap sebagai penjelasan terhadap segala ucapan Nabi, maka mengikutinya berarti pula mengikuti ucapannya. Keempat, perbuatan Nabi pasti mengandung kebenaran, maka mengikutinya berarti mengikuti kebenaran. ${ }^{68}$

Selintas pandangan di atas memang mengindikasikan bagaimana para Sahabat menganggap Muhammad sebagai nabi yang memang layak diikuti segala perilakunya. Namun demikian, jika dilihat lebih lanjut pandangan Nabi terkait persoalan kehidupan pribadi yang bersentuhan dengan sisi kemanusiaan kadang tidak menjadi perhatian tersendiri bagi para Sahabat. Karenanya kadang pula dalam hal ini Sahabat tidak kemudian mengikuti saran Nabi bahkan terkesan tidak menganggapnya sebagai perintah umum kepada para Sahabat.

Salah satu contohnya adalah yang terkait saran Nabi terhadap Barirah untuk ruju' dengan suaminya, Mughits.

${ }^{65}$ Muhammad ibn Ismail al-Bukhari, Sạhịh Bukhari, juz 2, 151.

${ }^{66}$ Muhammad ibn Ismail al-Bukhari, Sähịh Bukhari, juz 9, 96.

${ }^{67}$ Ibn Mājah, Sunān Ibn Mājah (Riyadh: Dār al-Ihyā' al-Kutub al-'Araby, tth) juz 1,493

${ }^{68}$ Shaif al-Dīn Abū Ḥasan al-Amidy, al-Ịhkam fị Ușūl al-Aḥkām (Beirūt: Dār alKutub al-'Ilmiyyah, 1983) 254-255. 


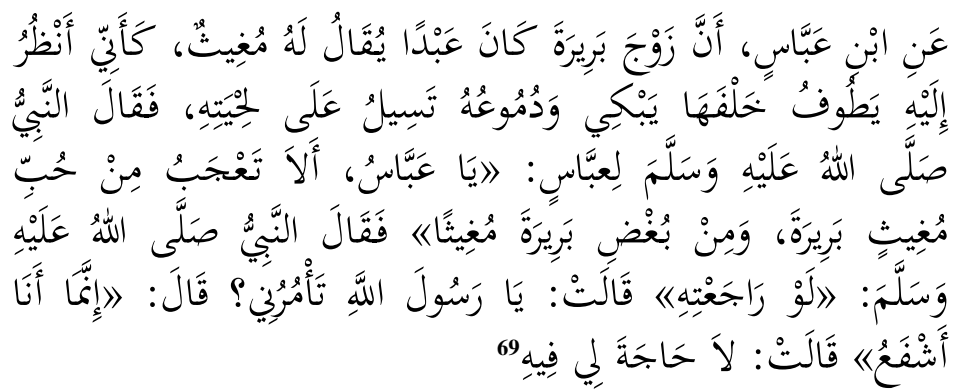

Secara jelas hadis di atas terlihat bagaimana seorang Sahabat juga menimbang perintah Nabi apakah perlu dilakukan atau tidak. Respon tersebut juga dapat difahami bahwa memang jika berkenaan dengan hal pribadi yang kadang tidak terkait agama seperti soal sikap suka dan tidak pada seseorang, tentu tidak ada kewajiban untuk mengikuti perintah tersebut.

Selain hal pribadi, ternyata Sahabat juga memberikan sebuah pertimbangan tentang sikap dan perintah Nabi, yakni apakah perintah tersebut dari Allah atau hasil ijtihad pribadi Nabi. Tentunya ijtihad ini pasti terkait dengan hal keduniaan selain akidah dan ibadah yang memang Sahabat bahkan Nabi sekalipun tidak mungkin mengarangnya. Salah satu contohnya adalah sikap Sahabat Sa'ad ibn Mu'az dan sa'd ibn 'Ubadah kepada Nabi saat beliau إن قلت عن وحي، إن Hingga akhirnya Nabi pun mengungkapkan bahwa pendapatnya bukanlah wahyu melainkan taktik perang belaka. Di sinilah kemudian Nabi mengikuti pendapat kedua Sahabat tersebut dan meninggalkan pendapatnya sendiri.

Meskipun terdapat perbedaan apakah peperangan menjadi bagian dari ajaran agama atau tidak, namun disadari bahwa taktik perang adalah masalah pengalaman dan mengetahuan. Hal ini tentu berbeda dengan masalah ibadah dan akidah yang sahabat hanya menerima tanpa mempertimbangkannya kepada Nabi.

Dengan demikian bisa dilihat bagaimana kemudian ketaatan Sahabat kepada Nabi tidaklah buta melainkan dengan daya nalar yang sangat rasional. Setidaknya contoh di atas bisa memberikan gambaran sebagaimana berikut. Pertama, pokok persoalan kenabian adalah bagi Sahabat adalah wahyu. Karenanya, dalam berijtihad Nabi di depan Sahabat memiliki standar yang sama

${ }^{69}$ Muhamad ibn Isma'il al-Bukhari, Musnad al-Bukhari, juz 7, 48.

70 'Abdul Malik ibn 'Abdullah al-Juwaini (w. 478), Nihāyat al-Matlab fí Nihāyat al-Mazhab (Riyādh: Dār al-Manhaj, 2007) juz 18, 98; lihat juga 'Abdul 'Aziz ibn Ahmad al-Bukhari, Kashfu Al-Asrār 'An Usūul Al-Faḥr Al-Islamy Al-Bazdawy (Beirūt: Dār alKitab al-'Arabi, 1308 H), Juz 3, 210. 
dengan Sahabat lainnya. Kedua, Jika ijtihad Nabi tersebut terkait soal privasi Sahabat dalam hal yang diperbolehkan, maka Sahabat akan memilih sebagaimana yang mereka anggap baik. Ketiga, namun demikian, wahyu sebagai keistimewaan Nabi dalam berkomunikasi kepada Tuhan dianggap mampu menjembatani segala kesalahan, artinya mengikuti Nabi dalam hal apapun hampir tidak mungkin jatuh pada tindakan dosa. Karenanya sebagian orang menganggap bahwa mengikuti Nabi dalam segala hal adalah baik, meskipun tidak ada janji pahala di dalamnya.

\section{Penutup}

Ijtihad adalah bagian dari proses penalaran manusia terhadap apa yang terjadi di sekitarnya dalam memecahkan persoalan. Tak beda dengan seorang Nabi yang mendapat wahyu, namun kadang kala dihadapkan dalam persoalan yang mengharuskan adanya jawaban yang cepat atau bahkan memiliki gagasan sendiri tanpa harus menunggu wahyu. Karenanya ijtihad seorang Nabi sebagai penerima wahyu yang juga manusia tidaklah bisa dipisahkan. Dengan mendalami adanya ijtihad dalam diri seorang Nabi justru memahamkan bahwa setiap tindakan Nabi ataupun bahwa wahyu yang didapatkannya tidaklah terlepas dari kondisi sosial dan budaya dimana beliau hidup. Namun kenabian tetaplah lebih utama dari kemanusiaan itu sendiri, karena memang wahyu lebih utama dari ijtihad. Dan karenanya pula ijtihad seorang Nabi sangat mungkin lebih utama dari pada ijtihad manusia biasa. Wallahu a'lam.

\section{Daftar Pustaka}

'Abd al-Jalil Isa Abū al-Naṣr, Ijtihād al-Rasūı Salla Allāhu 'Alaihi wa Sallam (Kairo: Dār al-Ihyya’ al-'Arabi, 1950).

'Abd al-Rahmān ibn Muhammad ibn Khaldūn, Al-Muqaddimah (Maroko: Dar al-Baidha', 2005).

'Abd al-Wahhab Khallāf, Mạsādir al-Tashri' al-Islām (Kuwait: Dār al-Qalamī, 1972).

'Abdul 'Azīiz ibn Ahmad al-Bukhari, Kashfu Al-Asrār 'An Usūul Al-Fahr AlIslamy Al-Bazdawy (Beirūt: Dār al-Kitab al-'Arabi, $1308 \mathrm{H})$.

'Abdul Malik ibn 'Abdullah al-Juwaini (w. 478), Nihāyat al-Matlab fì Nihāyat al-Mazhab (Riyādh: Dār al-Manhaj, 2007).

'Ali Shaifuddin al-Amidi, al-Iḥkām fí 'USūul al-Aḥkām (Beirūt: Dār al-Kutub al'Ilmiyyah, Tth). 
'Ata ibn Khalil, Taysīr al-Wuṣūl ilāa al-Uṣul: Dirāsat fì Uṣul al-Fiqh (Beirūt: Dār al-Ummah, 2000).

Abdul Jalil Isa Abu al-Nasr, Ijtihad Rasulullah Saw. terj. Wawan Djunaedi. (Jakarta: Pustaka Azzam, 2001).

Abdul Kabir Husain Solihu, "Revelation and Prophethood in The Islamic Worldview." Journal of Islam in Asia 6, no. 1 (2009).

Abdul Wahab Khallāf, 'Ilm Ușūl al-Fiqh (Kuwait : Dār al-Qalam, 1978).

Abu 'Abdullah al-Qurțubi (w. 671), al-Jāmī' al-Ahkām al-Qur'ān, (Kairo: Dār al-Kutub, $1964 \mathrm{M})$.

Abu Abdurrahman al-Nasa'i (w. 303), Sunan al-Nasa'i (Beirūt: Muassasah Risalah, 2001).

Abu Daud, Sunan Abū Daud(Beirūt: Maktabah Asriyah, tt).

Abu Hafz Siraj al-Dìn al-Dimasqy (w. 775 H), al-Lubbāb fí 'Ulūm al-Kitāb (Beirūt: Dār al-Kutub al-'Imiyyah, 1997).

Abū Bakr Ahmmad ibn Ibrahim al-Isma’ili, al-Mu’jam fí Asāmi Shaikh Abi Bakr al-Ismà'ily, (Madinah: Maktabah al-'Ulūm wa al-Hukm, $1410 \mathrm{H}$ ).

Abū Daūd Sulaimān al-Sijistānī (w. 275 H), Sunan Abū Daūd (Beirut: Maktabah al-'Asriyah, Tth).

Abū Hamīd Muhammad al-GhazāTi, al-Mushtashfā min 'Ilmi al-'Usūù (Kairo: Muassasah al-Halabi, Tth).

Abū Muhammad ibn Hazm al-Andalūsì al-Zahiri, al-Ihkām fi Usūul al-Aḥkām (Kairo: Sa'adah, Tth).

Abū Muhammad Abdullah al-Darimīi, Musnad al-Darimīi, (Saudi: Dār alMughni, 2000).

Abū Sa'id ibn al-'Araby, Mu'jam ibn al- 'Araby (Saudi: Dār ibn Jauzi, 1997).

Adis Duderija, "Toward a Methodology of Understanding the Nature and Scope of the Concept of Sunnah." Arab Law Quarterly 21 (2007).

Aḥmad ibn al-Husain al-Baihaqi, Ma'rifat Sunan wa al-Ațar (Beirūt: Dār alQuṭbiyyah, 1991).

Aḥmad Maṭar Khaḍir, "Mushāwarāt al-Rasūl Saw Li Aṣhābihi fĩ al-Ghazawāt." Jurnal Research Diyala Unversity (2009).

Al-Baidhawi, Minhājul Wusūl, (Beirūt: Muassasah Risalah, 2006).

Al-Ghazali, Al-Mankul min Ta’liqāt al-UṢul (Damaskus: Dār al-Fikr, 1400 H).

Al-Juwaini, Al-Burhān fì Ușul al-Fiqh (Mesir: al-Wafa', 1418 H).

Al-Qađ̣i 'Iyad, al-Shifa' (Kairo: al-Matba' ah al-Azhariyah, 1327 H).

Al-Shaukani, Irshād al-Fuhul ilā Tahqīq al-Ḥaq min 'Ilm al-Ushul (Beirūt: Dār al-Kutub al-'Ilmiyyah, 1999). 
Faḥd Talāl Salim al-Khalidy "Al-Manhaj al-Nabawy fî al-Ta‘āmul al-Usrā." College of Basisc Education Researches 4 (2007).

Fazlur Rahman, Major Themes of the Qur'an (Minneapolis: Bibliotheca Islamica, 1994).

Hakim 'Abd Nāșir, "Mawqif al-Falsafah al-Muslimīn min al-Nubuwwah." Adāb al-Kufa 1, (2011).

Ibn Atsir, Asād al-Ghābah fì Ma’rifat al-Sahābah (Kairo: Dār Kutūb al'Ilmiyyah, 1994).

Ibn Katsir (w. 774 H), Tafsìr al-Qurān al- 'Azīm (Kairo: Dār al-Tayiibah, 1999).

Ibn Mājah, Sunān Ibn Mājah (Riyādh: Dār al-Ihyā' al-Kutub al-'Araby, tth).

Ibn Munzir, Lisān al- 'Arab (Beirūt: Dār al-Sin al-'Arab, tth).

Ibn Qatadah, Ta’wīl Mukhtalif al-Hadith (Beirūt: Dār al-Fikr, 1995).

Ibn Qayyim, Miftāh Dār al-Sa'adah (Beirut: Dār al-Kutub al-'Ilmiyyah, 1993).

Imān Khalifah Hamīd, "Al-Mandūmāt al-Khịtābiyah fì al-Aḥādith alQudsiyah.” Al-Tarbiyah wa al-'Ilm 13, no. 4 (2006).

John L. Esposito, Terj. Arif maftuhi, Islam Warna-Warni (Jakarta: Paramadina, 2004).

Khatib al-Bagdady, Kitāb al-Kifāyah fí 'Ilm al-Riwāyah (Beirūt: Dār al-Kutub, 1988).

Latifah Abdul Majid dan Mohd Nasir Abdul Majid, "Perkaitan Antara Ayat alKitab dengan ijtihad Rasulullah Saw," Islamiyyat 32 (2010).

M. Sayyid Ṭantawi, Konsep Ijtihad Dalam Hukum Syarak. Terj. Safri Mahayedin, (Kuala Lumpur: Institute Terjemahan Negara Malaysia, Cet. 2 2009).

M.M. Azami. Hadis Nabi dan Sejarah Kodifikasinya (Jakarta: Pustaka Firdaus, 2000).

Mahmut Shaltut, al-Islām: 'Aqīdah wa Shari'ah (t.tp.: Dār al-Qalam, 1966).

Malak Muhammad Thabit 'Abd al-Hamid, "Mafhūm al-Nubuwwah wa al-I'jāz 'inda al-Muslimin.” Jurnal of The Iraqi University 25, no. 1 (2010).

Marwah Ibrahim Sya'ban, "al-Ahāadith al-Qudsiyah: Dirāsah Balaghiyah." Thesis (2007), Fakultas Adab, Universitas Ghaza.

Mohammad Nazami, "Ijtihad: Takhti'ah or Tașiib." Message of Thaqalayn, A Quarterly Journal of Islamic Studies 10, no. 2 (2009).

Muḥammad ibn Ḥibbān (w. 354), Sahịh ibn Hibbān, (Beirūt: Muassasah Risālah, 1993).

Muhammad Sulaimān al-Ashqār, Af'āl al-Rasūl wa Dalālatuhā 'ala al-Aḥkām al-Shar'iyyah (Kuwait: Maktabah al-Manār al-Islamy, 1976). 
Muhammad ibn Ismail al-Bukharī, Musnad al-Sahịh, (Kairo: Dār al-Tauq alNajah, $1422 \mathrm{H})$.

Muhammad ibn Jarir al-Tabarì, Jāmi' al-Bayān fí Ta'wīl al-Qurān (Riyādh: Muassasah al-Risalah, 2000).

Muslim ibn Hajjāj al-Nisaburi, Saḥị̣ Muslim (Beirūt: Dār al-Ihya' al-Turath, Tth).

Saim Kayadibi, "Ijtihad by Ra'y: The Main Source of Inspiration behind Istihsan", The American Journal of Islamic Social Science 24, no 1, (2007).

Syah Waliyullah al-Dahlawi, Hujjatul al-Bālighah (Beirūt: Dār al-Ma'rifah, tth). Yusuf al-Qaraḍ̄wīi, al-Sunnah Mașdaran li Ma'rifah wa al-Hadarah. cet. 3, (Kairo: Dār al-Surūq, 2002).

Zainuddin MZ, "Kontroversi al-Hadith al-Syarif Wahyu Ilahi Atau Ijtihad Nabi?” Sunan Ampel, Jurnal Profetika 9, no. 1, (2007). 